\title{
TINDAK TUTUR ILOKUSI PADA CAPTION COVID-19 DI MEDIA SOSIAL
}

\author{
Leli Nisfi Setiana ${ }^{1}$, Evi Chamalah², Cahyo Hasanudin ${ }^{3}$ \\ Universitas Islam Sultan Agung ${ }^{1}$, Universitas Islam Sultan Agung ${ }^{2}$, IKIP PGRI Bojonegoro³ \\ lelinisfi@unissula.ac.id ${ }^{1}$
}

\begin{abstract}
Abstrak
Peradaban manusia tidak lepas dari unsur penting yang terdapat di dalamnya yaitu kegiatan berkomunikasi. Bahasa merupakan alat komunikasi utama yang digunakan oleh manusia dalam berkomunikasi sehari-hari. Di Era Revolusi industri 4.0 yang semakin canggih, dimana semua hampir seluruh lapisan aktivitas manusia bersentuhan dengan dunia digital. Pandemi Covid-19 menjadikan masyarakat milenial kerap kali meluapkan ekspresinya dalam bentuk caption di media sosial. Beberapa media sosial yang kerap menjadi objek masyarakat dalam mengunggah caption Covid-19 yaitu di Facebook, WhatsApp, Twiiter dan Instagram. Semakin maraknya caption di media sosial tersebut yang menyoroti tentang Covid-19 menjadi salah satu alasan utama dalam melakukan penelitian ini. Tujuan penelitian ini adalah untuk mendeskripsikan dan mengidentifikasi realisasi tindak tutur ilokusi (asertif, direktif, ekspresif, komisif, dan deklarasi) pada caption Covid-19 di media sosial. Data penelitian ini diambil dari berbagai sumber di media sosial diantaranya WA, FB dan Instagram. Metode penelitian yang digunakan adalah metode deskriptif. Penelitian ini merupakan mendeskripsikan tindak tutur ilokusi yang terdapat dalam caption Covid-19 di media sosial. Berdasarkan hasil penelitian dapat diambil simpulan bahwa terdapat bentuk tindak tutur ilokusi pada caption di media sosial Twitter, WhatsApp, Facebook dan Instragam yaitu tindak tutur asertif terdapat 1 data, direktif terdapat 8 data, ekspresif terdapat 2 data, komisif terdapat 1 data, deklarasi terdapat 3 data dengan total keseluruhan adalah 18 data.

Kata kunci: Tindak Tutur Ilokusi, Caption, Media Sosial
\end{abstract}

\section{PENDAHULUAN}

Perkembangan manusia yang semakin pesat disebabkan oleh kemampuan berbahasa yang baikm oleh masyarakatnya. Kecanggihan teknologi pada Eda Revolusi Industri 4,0 seiring dengan berkembangnya media sosial yang mempermudah komunikasi. Kehadiran facebook, whatsApp, dan instagram menjadi warna dan bentuk komunikasi yang berbeda dengan alat komunikasi lainnya. Bahasa yang terdapat di caption media sosial akan menarik jika diteliti lebih dalam lagi, karena caption mungkinberisi tentang himbauan, sindiran, atau ancaman. Berdasarkan alasan inilah peneliti merasa tertarik untuk meneliti lebih dalam tentang tindak tutur ilokusi yang terdapat pada caption di media sosial.

Semakin maraknya caption di media social baru-baru ini menyoroti tentang Covid-19 atau disebut juga virus corona. Sejarah singkat Covid-19 yang mewabah di China sejak Desember 2019 sampai sekarang, virus corona telah menginfeksi lebih dari 110.000 orang dengan pasien meninggal mencapai lebih dari 3.600 orang di lebih 80 negara di seluruh penjuru dunia dan menyebutnya sebagai pandemi internasional. Dampak langsung yang terjadi akibat Covid-19 di Indonesia adalah dengan berlakunya "Social Distancing" atau yang disebut jaga jarak dan dilarang berkumpul di keramaian. Hal tersebut menjadikan banyak netizen bercuitan dalam bentuk caption 
di media sosial. Diantaranya caption tersebut ada yang berisi mengenai humor, himbauan, perasaan galau dan sindiran mengenai Covid-19. Media sosial yang paling banyak diminati oleh masyarakat pada saat ini adalah whatsApp, facebook, dan instagram. Banyak media sosial lainnya akan tetapi untuk penelitian ini peneliti akan menganalisis caption pada whatsApp, facebook, dan instagram saja terkait dengan Covid-19. Caption Covid-19 di media sosial memiliki makna tersirat akan lebih tepat diteliti menggunakan tindak tutur ilokusi.

Berdasarkan latar belakang dan fokus penelitian yang telah diuraikan di atas, maka diperoleh judul penelitian "Tindak Tutur Ilokusi Pada Caption Covid-19 di Media Sosial." Rumusan masalah dalam penelitian ini adalah bagaimana bentuk tindak tutur ilokusi pada caption Covid-19 di media sosial? Tujuan penelitian ini adalah mendeskripsikan bentuk tutur ilokusi pada caption Covid-19 di media sosial.

\section{Tindak Tutur}

Chaer (2010:50) mengungkapkan peristiwa tutur (speech event) adalah gejala sosial yang diakibatkan dari adanya interaksi antar penutur yang dipengaruhi oleh situasi dan tempat bertutur yang cenderung bersifat individual psikologis seseorang, yang ditemtukan dari penggunaan bahasa penutur ketika menghadapi suatu situasi tuturan. Sedangkan menurut Yule (2006:81) tindak tutur adalah usaha mengungkapkan jati diri mereka tidak hanya menghasilkan sebuah tuturan yang tersusun secara gramatikal, yang perlu memperhatikan tindakan dalam situasi tuturan. Komunikasi akan berjalan dengan baik ketika penutur mampu mengungkapkan maksud tuturannya, sehingga mampu dipahami oleh lawan tutur.

Searle (Rahardi, 2005:36) mengungkapkan bahwa tindak tutur dalam penggunaan bahasa, pertama adalah tindak tutur lokusi terdiri dari penggunaan dan makna dari kata, frasa, dan kalimat. Kedua, tindak tutur ilokusi, yaitu tindak tutur untuk melakukan sesuatu dengan maksud dan fungsi tertentu pula. Ketiga, tindak tutur perlokusi, yaitu tindak tutur yang memberikan pengaruh) kepada lawan tuturnya. Penelitian ini berfokus kepada tindak tutur ilokusi. Menurut Searle (Rahardi, 2005:36) mengelompokan tindak tutur ilokusi menjadi a. Asertif, yaitu menitikberatkan kepada kebenaran proposisi yang diungkapkan dalam situasi tuturan. b. Direktif, yaitu bentuk tindakan yang dimaksud oleh penuturnya menjadi hal yang harus diperhatikan, agar makna atau maksud yang penutur sampaikan dapat dipahami oleh mitra tutur c. Ekspresif, yaitu fungsi utama dalam tuturan ini untuk menunjukan sikap psikologis penutur pada sebuah situasi tuturan. d. Komisif, yaitu tuturan berbentuk penawaran atau pernyataan. e. Deklarasi, yaitu tuturan dan kenyataan saling berhubungan. 
2. Caption Media Sosial

\subsection{Caption}

Deskripsi berupa tulisan yang menyiratkan pada sebuah ilustrasi atau foto. Definisi lain mengungkapkan caption adalah sebuah keterangan atau penjelasan tentang sebuah ilustrasi gambar atau foto yang diposting di media sosial. Dewasa ini caption masyarakat milenial semakin berani dan tanpa basa-basi. Berbagai bentuk caption dituliskan baik yang mengandung unsur positif maupun negatif. Caption banyak terdapat di media sosial berupa Facebook, WhatsApp, Twiiter dan Instagram.

Boyd dan Ellison mendefinisikan jejaring sosial yang mampu membangun profil baik secara umum atau semi-umum layanan berbasis, daftar koneksi tidak terbatas baik itu yang dibuat oleh sendiri ataupun daftar koneksi pengguna lain yang terjaring dalam jaringan sosial.

Bryer dan Zavattaro dalam Chen \& Bryer, "Media sosial menjadi sebuah wadah interaksi sosial masyarakat milenial, dimana banyak hal dapat dilakukan tanpa batas, lebih fleksibel serta efisien waktu. Teknologi yang termasuk dalam media sosial yaitu blog, wiki, media (audio, foto, video, teks) alat berbagi, platform jaringan (termasuk Facebook), dan dunia virtual." Adapun tren media sosial di Indonesia pada saat ini adalah WhatsApp, Twiiter, Facebook, dan Instagram.

Menurut Nurudin (2012) secara substansial dari jejaring sosial adalah bagaimana mengubah cara berkomunikasi antar masyarakat baik umum, organisasi maupun idividu. Jenis- jenis media sosial menurt Nuridin adalah (1) Facebook adalah media sosial yang mudah digunaka dalam berkomunikasi, memiliki aplikasi yang besar mampu menampung banyak teman, sehingga Facebook menjadi primadona pertama yang banyak diminatdiminati oleh masyarakat Indonesia. (2) Twitter adalah sebuah situs web yang memiliki banyak penawaran kemudahan dalam melakukan jejaring sosial untuk mengirin dan membaca pesan serta memberikan komentar yang sering disebut dengan istilah kicauan. (3) WhatsApp adalah perangkat selular yang memiliki kemampuan layanan laman, telepon, chat, menjelajahi internet dan mudah digunakan, sehingga WhatsApp menjadi primadona dikalangan masyarakat. (4) Instagram merupakan sebuah aplikasi yang didominasi oleh foto, dapat mengirim dan membagikannya secara bebas ke berbagai media sosial lainnya dengan disertai caption agar tampak lebih menarik perhatian pembacanya.

Media sosial adalah digunakan untuk melakukan interaksi sosial berbasis web yang mengkombinasikan antara ruang lingkup dunia maya dalam bentuk seperti blog, zoom meeting, email, dan juga kekuatan komunitas yang dibangun pada media sosial yaitu facebook, whatssApp, 
twiiter dan instagram. Media sosial juga dapat digunakan untuk berbagi informasi, sehingga aktivitas di dunia maya kian terasa ada digenggaman tangan.

Berdasarkan beberapa pendapat mengenai caption dan media sosial, maka diperoleh simpulan bahwa caption selalu berkaitan erat dengan media sosial. Caption mengekpresikan suatu deskripsi sebagai keterangan dari ilustrasi pada gambar atau foto yang diposting di media sosial berupa facebook, whatsApp, twiteer dan instagram.

\section{METODE PENELITIAN}

\section{Jenis Penelitian}

Penelitian ini termasuk dalam kategori penelitian deskriptif. Penelitian deskriptif menurut Arikunto adalah (2010:3) mengungkapkan penelitian deskriptif dilakukan dalam rangka melakukan penyelidikan terhadap suatu keadaan, situasi dan kondisi yang telah ditentukan sebagai objek penelitian. Pada penelitian ini implementasi penelitian deskriptif adalah memaparkan atau menggambarkan permasalahan mengenai tindak tutur ilokusi pada caption Covid-19 di media sosial.

2. Objek kajian dalam penelitian ini adalah caption Covid-19 di media sosial. Lokasi penelitian ini adalah di media sosial whatsApp, facebook, dan instragram seluruh Nusantara.

\section{Teknik Pengumpulan Data}

Penelitian menggunakan teknik pengumpulan data berupa teknik simak dan catat. Mahsun (2012:92) mengungkapkan teknik simak dilakukan dengan menyimak penggunaan bahasa sebagai objek datanya. Implementasi teknik simak dalam penelitian ini adalah beupa data tertulis yang terdapat pada caption Covid-19 di media sosial. Menurut Mahsun (2012:92) teknis catat adalah teknik lanjutan ketika menerapkan metode simak. Selanjutnya, peneliti akan menggunakan teknik dokumen guna melengkapi proses teknik pengumpulan data penelitian. Bentuk dokumen dalam penelitian ini adalah berupa screenshoot caption Covid-19 di media sosial yang selanjutnya

\section{Teknik Analisis Data}

Beberapa langkah yang dilakukan dalam proses analisis data yaitu:
a) Reduksi Data 
Data yang telah diperoleh dalam penelitian ini kemudian dilakukan reduksi data. Gambaran tentang hasil pengamatan terhadap data selanjutnya oleh peneliti disusun secara sistematis. Selain digunakan sebagai pengamatan terhadap data penelitian. Pemberian kode data sesuai dengan kategori yang meliputi asertif, direktif, ekspresif, komisif, dan deklarasi caption Covid-19 di media sosial akan lebih mudah dengan menggunakan reduksi data.

b) Data display (penyajian data)

Kegiatan selanjutnya adalah mendisplaykan data penelitian atau disebut juga penyajian data dalam kegiatan analisis data kuantitatif hasil penelitian. Sedangkan dalam kegiatan penelitian kuantitatif data display dalam bentuk deskripsi singkat, bagan, flowchart dan sebagainya. Penyajian data kualitatif dalam penelitian ini bersifat naratif terhadap caption Covid-19 di media sosial, sehingga peneliti dapat lebih mudah memahami dan merencanakan kerja tahap penelitian selanjutnya.

c) Penarikan kesimpulan/verification

Peneliti banyak membaca penelitian sebelumnya dan yang relevan dengan penelitian ini. Berbagai objek peneliti temukan di dalam caption Covid-19 di Facebook, WhatsApp, Twiiter, dan Instagram, akan tetapi peneliti kemudian mengklasifikasikan yang termasuk ke dalam kategiri tindak tutur ilokusi. Setelah peneliti memperoleh data hasil penelitian dan membahas data penelitian tersebut pada aahirnya diperoleh kesimpulan dari data yang terkumpul menjadi sesuai dengan kategori tindak tutur asertif, direktif, ekspresif, komisif, dan deklarasi.

\section{Keabsahan Data}

Teknik triangulasi merupakan teknik pemeriksaan keabsahan tindak tutur ilokusi caption Covid-19 di media sosial. Menurut Denzim (Moleong, 2012:330) mengungkapkan bahwa terdapat empat macam bentuk triangulasi yaitu pemeriksaan dilakukan dengan penggunaan sumber, teori, penyelidikan dan metode. Berdasarkan definisi teknik triangulasi tersebut, penelitian ini menggunakan teknik penyidik dan teori. Moleong (2012:331) mengungkapkan teknik penyidikan dengan melakukan pengecekan kembali terhadap data, sehingga dapat tetap menjaga original atau kepercayaan terhadap pemanfaatan hasil penelitian agar tidak melenceng dalam kegiatan pengumpulan datanya. 


\section{HASIL DAN PEMBAHASAN}

\section{Hasil Penelitian}

Peneliti mendapatkan hasil penelitian yaitu untuk jumlah keseluruhan realisasi tindak tutur ilokusi (asertif, direktif, ekspresif, komisif, dan deklarasi) pada bentuk tindak tutur ilokusi pada caption di media sosial WhatsApp, Facebook dan Instragam yang meliputi asertif (AS), direktif (DE), ekspresif (ES), dan deklarasi (DE). Hasil penelitian yang ditemukan bentuk tindak tutur asertif ditemukan sebanyak 1 data, direktif sebanyak 8 data, ekspresif sebanyak 2 data, deklarasi sebanyak 3 data dengan total data sebanyak 16 data. Bentuk tindak tutur deklarasi paling banyak ditemukan sebanyak 8 data pada caption media sosial, sedangkan tindak tutur ilokusi asertif sebanyak 1 data.

2. Pembahasan

Berdasarkan hasil penelitian, diperoleh data dan deskripsi penelitian yang terinterpretasikan dalam bentuk pembahasan sebagai berikut:

"Jadilah terang dalam kegelapan" (Data 2/ILO/DIR/2.02)

Caption Covid-19 yang terdapat di WhatsApp tersebut termasuk dalam kategori tindak tutur ilokusi direktif, yaitu berkaitan dengan peristiwa hari Kartini, 21 April 2020 banyak sekali posterposter yang bertuliskan kutipan tersebut, yang memberi makna "Habis Gelap Terbitlah Terang" tidak akan hilang di tengah pandemi. Justru Kartini- Kartini masa kini menjadi sinar untuk menginspirasi publik, peran mereka di dunia maya, nyata dan di garis depan (perawat).

"Kamu di rumah aja ya. Kalau haus, minum. Kalau laper, makan. Kalau di chat dibales. Jangan dibaca doing” (Data 3: ILO/DIR/3.03)

Caption Covid-19 yang terdapat di Instagram termasuk dalam kategori tindak tutur ilokusi direktif, yaitu terdapat kata-kata yang mengacu pada ilokusi ekspresif sebagai wujud tambahan menariknya kutipan tersebut. Dari kalangan masyarakat luas tidak sedikit yang tidak menaati peraturan untuk berada di rumah saja, padahal masa pandemi adalah masa yang berbahaya yang di harapkan masyarakat taat untuk mengurangi angka peningkatan kasus covid-19.

"Saatnya kita lockdown hawa nafsu, Mensterilisasi dosa-dosa, Mumpung ada PSBB (Pahala Shaum Berskala Besar)" (Data 4: ILO/DEK/4.04) 
Caption Covid-19 yang terdapat di Facebook termasuk dalam kategori tindak tutur ilokusi deklarasi, yaitu memang seharusnya sebagai umat muslim wajib membersihkan diri dari hawa nafsu yang mampu menjerumuskan pada kesalahan atau dosa, baik itu berupa hawa nafsu dari lahir maupun batin. Adapun pesan moral yang terdapat pada kutipan tersebut adalah, pesan untuk menjaga hawa nafsu manusia di saat berpuasa maupun dikehidupan biasanya, seharusnya umat manusia lebih mempersiapkan bekal untuk nanti di akhirat bukan untuk menuruti hawa nafsu.

"Nyong pada tetep nang puskesmas Kedungbanteng demi rika-rika. Tulung rika pada

tetep nang umah. Demi nyong pada.” (Data 5: ILO/DIR/5.05)

Caption Covid-19 yang terdapat di Facebook termasuk dalam kaetogi tindak tutur ilokusi direktif yaitu bentuk pengaruh yang ditujukkan kepada warga masyarakat untuk tetap di rumah, demi semua orang, bukan hanya tim medis. Karena sempat beberapa waktu lalu para garda terdepan mulai lelah ketika menghadapi melonjaknya kasus positif Covid-19 yang signifikan karena kurangnya kesadaran masyarakat untuk tetap di rumah.

"Kalian tetap di rumah untuk kami, Kami tetap bekerja untuk kalian" (Data 6: ILO/KO/6.06)

Caption Covid-19 yang terdapat di WhatApp termasuk tindak tutur ilokusi komisif, yaitu menyatakan janji atau penawaran dari nakes kepada masyarakat untuk tetap berada di rumah dengan tawaran nakes akan tetap bekerja untuk kesembuhan warga yang terpapar Covid-19. Beberapa nakes kerap kali mengingatkan semua lapisan masyarakat untuk tetap berada di rumah di masa pandemi untuk meminimalisasi penularan Covid-19.

"Seakan corona lebih menakutkan dari neraka. Kalian berebut masker karena takut terdampak virus corona. Andai Allah SWT tampakkan neraka, niscaya mereka berebut hijab untuk tutup aurat". (Data 7: ILO/AS/7.07)

Caption Covid-19 yang terdapat di Facebook termasuk dalam kategori tindak tutur ilokusi asertif, yaitu kebenaran proposisi dalam artian kelak di akhirat kita diminta pertanggung jawaban atas perbuatan kita, diantaranya mengenai bagaimana kita hidup di dunia dengan aurat kita? Apakah kita mampu menutupi atau justru malah mengumbarnya. Padalah selama ini kita sering belajar ilmu agama namun, masih saja terlena oleh beberapa style yang membuat kita ikut mencobanya. 
"Pantang pulang sebelum corona tumbang" (Data 8: ILO/ES/8.08)

Caption Covid-19 yang terdapat di WhatsApp termasuk dalam kategori tindak tutur ilokusi ekspresif, yaitu menyatakan atau menunjukkan sikap psikologis para nakes untuk tetap melakukan tugasnya di kala pandemi, demi penekanan jumlah positif terpaparnya covid-19. Selama ini para perawat dan tim medis lainnya bertahan untuk berjuang bahkan rela jauh degan keluarganya, bekerja penuh lelah dengan alat pelindung diri yang begitu ketat menyelimuti tubuhnya demi melindungi kita semua.

“Ojo metu nak njobo. Nang njero wae Mas..” (Data 9: ILO/DIR/9.09)

Caption Covid-19 yang terdapat di Instagram termasuk dalam kategori tindak tutur ilokusi direktif, yaitu membuat pengaruh agar si mitra tutur melakukan tindakan tetap berada di rumah. Anjuran tersebut sangat sering kita jumpai di saat masa pandemi ini. Bahkan pemerintah dan tim medis tidak pernah lelah untuk menganjurkan masyarakat untuk berada di rumah apabila tidak memiliki kepentingan mendesak. Pesan moral yang kita dapat dari kutipan tersebut adalah pesan untuk selalu meningkatkan kesadaran diri demi semua orang yang berada di sekitar kita.

“Tidak mudik bukan tak ingin bertemu tapi demi masa depanmu" (Data 10: ILO/DE/10.10)

Caption Covid-19 yang terdapat di Twiiter termasuk dalam kategori tindak tutur ilokusi deklarasi, yaitu menghubungkan isi tururan dengan kenyataan, walau belum pasti namun mencegah lebih baik baik mengobati karena penyakit ini tidak macam-macam sekali terpapar butuh penanganan yang serius. Pemerintah melarang keras adanya kegiatan rutin mudik di setiap tahunnya, pasalnya ini sebagai bentuk penekanan angka positif covid-19 yang lebih banyak terjadi di kota-kota besar seperti Jakarta dan sekitarnya, pemerintah mewanti-wanti agar masyarakat desa tidak tersentuh oleh paparan covid-19. Pesan moral yang terdapat dalam kutipan tersebut adalah untuk tetap menjaga ketertiban yang menjadi kewajiban kita demi saudara-saudara agar tidak terpapar covid-19.

"Daripada di rumah sakit, apalagi di rumah duka, lebih baik di rumah saja. Jangan keluar, jangan tertular, jangan nularin" (Data 11: ILO/DIR/11.11)

Caption Covid-19 yang terdapat di WhatsApp termasuk dalam kategori tindak tutur ilokusi direktif, yaitu membuat pengaruh agar si mitra tutur melakukan tindakan di rumah saja. Ini sebagai upaya untuk meminimalisasi penularan covid-19 yang setiap hari semakin meningkat kasus positifnya. 
"Kamu di rumah ya, agar tau rasanya titip rindu lewat doa" (Data 12: ILO/ES/12.12)

Caption Covid-19 yang terdapat di Instagram termasuk dalam kategori tindak tutur ilokusi ekspresif yaitu menyatakan atau menunjukkan sikap psikologis salah satu warga terhadap masyarakat lain untuk tetap berada di rumah supaya ikut merasakan rindu kepada oang lain baik itu keluarganya yang bekerja sebagai garda terdepan maupun sanak saudara yang belum bisa mudik yang hanya bisa di temukan dari lantunan doa. Beberapa nakes dan garda terdepan lainnya bahkan tidak sempat untuk bertemu dengan keluarganya sebagai bentuk pengurangan penularan covid-19, maka dari itu mereka memang harus siap untuk berjarak untuk semantara demi keluarga di rumah, begitupun keluarga dirumah.

”Stop penyebaran sebar kebaikan" (Data 13: ILO/DIR/13.13)

Caption Covid-19 yang terdapat di Facebook termasuk dalam kategori tindak tutur ilokusi direktif, yaitu membuat pengaruh agar si mitra tutur melakukan tindakan menyebar kebaikan bukan penyebaran virus. Hal ini dilakukan untuk meminimalisasi penyebaran covid-19.

“Jarak menguatkan kita \#stop penyebaran" (Data 14: ILO/DE/14.14)

Caption Covid-19 yang terdapat di Twiiter termasuk dalam kategori tindak tutur ilokusi deklarasi, yaitu menghubungkan kenyataan saat ini kita harus menjaga jarak untuk mengurangi penyebaran Covid-19. Tidak selamanya yang berdekatan membawa kebahagiaan da nada kalanya jarak menjadi penguat daya tubuh kita agar terhindar dari paparan virus Corona

“Tak saling bertatap wajah tapi saling mendoakan” (Data 15: ILO/DIR/15.15)

Caption Covid-19 yang terdapat di WhatsApp termasuk dalam kategori tindak tutur ilokusi direktif, yaitu membuat pengaruh agar si mitra tutur dapat melakukan tatap wajah atau muka secara virtual saja dan saing mendoakan untuk kesehatan semua manusia terutama mereka sang tenaga medis yang berjuang untuk kita. Doa merupakan salah satu komunikasi terbaik untuk dia dan kepada Tuhan. Ketika manusia berdoa dengan sungguh-sungguh, akan dapat menambah imun positif dan meringankan beban saudara kita yang sedang terdampak pandemi.

"Pahlawan Corona sebenarnya adalah orang yang tetap di rumah. Bantu kami dengan tetap di rumah" (Data 16: ILO/DE/16.16)

Caption Covid-19 yang terdapat di Facebook termasuk dalam kategori tindak tutur deklarasi yaitu menghubungkan isi tuturan dengan kenyataan saat ini selain mereka garda terdepan sebagai pahlawan masyarakat juga bisa menjadi pahlawan dengan berada di rumah. Apabila kita berada di 
rumah sama halnya ikut membantu melawan penyebaran covid19. Pesan moral yang terdapat dalam kutipan tersebut adalah disiplinkan diri demi diri sendiri dan orang lain. Jika kita disiplin ikuti protokol kesehatan kita dapat dikatakan mampu mencegah diir sendiri dan orang lain terpapar covid-19.

\section{"Let's Stay Home” (Data 17:ILO/DIR/17.17)}

Caption Covid-19 yang terdapat di Instagram termasuk dalam kategori tindak tutur ilokusi Direktif yaitu membuat pengaruh kepada mitra tutur untuk tetap tinggal atau berada di rumah. Dalam artian mengurangi kegiatan di luar rumah untuk mencegah terpaparnya covid19. Pesan moral yang terdapat dalam kutipan tersebut adalah tetaplah pada wilayah atau tempat yang aman dan menjauhkan dari wabah atau bahaya.

\section{SIMPULAN}

Berdasarkan hasil penelitian dapat diambil simpulan bahwa terdapat bentuk tindak tutur ilokusi pada caption Covid-19 di media sosial WhatsApp, Facebook dan Instragam yang meliputi asertif (AS), direktif (DR), ekspresif (ES), Komisif (KO) dan deklarasi (DE). Hasil penelitian yang ditemukan bentuk tindak tutur asertif ditemukan sebanyak 1 data, direktif sebanyak 8 data, ekspresif sebanyak 2 data, komisif sebanyak 1 data, deklarasi sebanyak 4 data dengan total data sebanyak 16 data. Bentuk tindak tutur deklarasi paling banyak ditemukan sebanyak 8 data pada caption Covid-19 media sosial, sedangkan tindak tutur ilokusi asertif sebanyak 1 data. Dari uraian tersebut jumlah data yang didapatkan pada caption Covid-19 di media sosial ditemukan bahwa masyarakat milenial banyak memposting caption dengan bentuk tindak tutur direktif dengan fungsi menyatakan. Dalam penelitian ini pula tidak ditemukan bentuk tindak tutur komisif karena caption Covid-19 yang diposting tidak menunjukkan fungsi untuk menyatakan janji atau penawaran. Bentuk tindak tutur yang paling sedikit ditemui adalah asertif dengan satu fungsinya yaitu berpasrah.

Dengan berbagai telaah dan analisa yang telah dilakukan dalam penelitian ini, serta berdasarkan keterbatasan, maka dapat diberikan saran sebagai berikut:

a) Terkait hasil penelitian ini dan penelitian-penelitian yang sudah ada sebelumnya untuk bisa dijadikan pertimbangan dalam membuat suatu caption di media sosial.

b) Terkait permasalahan tindak tutur dan pesan moral dalam caption Covid-19 di media sosial belum dapat dikatakan maksimal. Hal ini disebabkan banyak data yang tidak ditemukan banyak tindak tutur yang terdapat dalam caption Covid-19. 
c) Perlu ditambahkan variabel penelitian lainnya sehingga dapat lebih memotret tindak tutur dan pesan moral pada caption Covid-19.

d) Untuk penelitian selanjutnya dapat menggunakan sampel dari populasi lain, jumlah sampel yang lebih besar dan beragam dengan proporsi dari varian variabel yang lebih komprehensif, serta dengan mengembangkan lebih lanjut mengenai tindak tutur dan pesan moral pada caption Covid-19 di media sosial.

\section{DAFTAR PUSTAKA}

Ali, Mohammad dan M. Asrori. (2012). Psikologi Remaja Perkembangan Peserta Didik.

Jakarta: Bumi Aksara

Boyd, D. M \& Ellison, N. B, "Social Network Sites: Definition, History, and Scholarship”, Journal of Computer-Mediated Communication, hlm.11 diakses pada 15 April 2021, pukul 10.15

Chen, T. Bryer, "Investigating instructional strategies for using social media in formal and informal learning," The International Review of Research in Open and Distributed Learning 13, no. 1 (2012): 87-104

Juju dan Sulianta, "Branding Promotion with Social Networks", Jakarta, PT. Elex Media Kompetindo, 2010, hlm. 4

Mahsun. (2012). Metode Penelitian Bahasa. Jakarta: PT Raja Grafindo Persada. Moleong. (2012). Metodologi Penelitian Kualitatif. Bandung: PT Remaja Rosdakarya.

Nurudin, “Munculnya Revolusi Baru Proses Komunikasi”, Yogyakarta, Litera, 2012, hlm. 54-80

Ramadhan, B. (2018, Februari Selasa). GoodNews From Indonesia. Retrieved Juni Selasa,

2018, from good news from Indonesia: https://www.goodnewsfromindone sia.id/2018/02/06/inilah perkembangan-digital-indonesiatahun-2018

Yule. (2006). Pragmatik. Yogyakarta: Pustaka Pelajar 